\title{
Studies on the surface ultrastructure of a snake tick, Amblyomma helvolum (Acari: Ixodidae)
}

\author{
Himadri Sikhar Ghosh $^{1}$, A. K. Sanyal ${ }^{2}$ and K. K. Misra ${ }^{*}$ \\ ${ }^{1}$ Department of Zoology, Asutosh College, University of Calcutta, Kolkata, India. \\ ${ }^{2}$ West Bengal Biodiversity Board, Kolkata, India. \\ *Corresponding author. Email:misrakk@vsnl.com. Tel: +91 9830149824, +919433565456.
}

Copyright (c) 2018 Ghosh et al. This article remains permanently open access under the terms of the Creative Commons Attribution License 4.0, which permits unrestricted use, distribution, and reproduction in any medium, provided the original work is properly cited.

Received 26th April, 2018; Accepted 23rd May, 2018

\begin{abstract}
A detail surface ultrastructure study on both male and female Amblyomma helvolum, inhabiting on snakes were made by using scanning electron microscope. The study unraveled the clear sexual dimorphism of the tick. Details of the surface ultrastructure were compared with other ixodid tick species as reported so far. Some distinctive surface morphology of $A$. helvolum was recorded viz., arrangement of hypostomal dentition, pore distribution on scutal surface, presence of festoons, position of male and female genital organ, number of spurs on different appendicular coxa, structure of spiracle and Haller's organ, number of sensilla on anterior pit of Haller's organ and distribution of different ventral idiosomal plates were remarkably diverse between sexes. Absence of festoons at the posterior extremity of female tick and absence of eyes on the antero-lateral sides of the scutum of both sexes of this tick species are the main outcome of this present study, which may provide insight to the traditional identification key of the genus Amblyomma.
\end{abstract}

Keywords: Adanal plate, Anterior pit, Gnathosoma, Idiosoma, Proximal capsule.

\section{INTRODUCTION}

Among all sanguinivorous insects, ticks are very common to act as a viaduct or vector of different zoonotic diseases. It transmits several pathogens and disease-causing agents like as virus, bacteria, protozoa etc. There are about 32 species of ixodid ticks belonging to 9 genera inhabiting on several reptilian, mammalian and avian host species identified from West Bengal, of which five species were collected from 13 different reptilian species (Sanyal and De, 1992). Infestation of snakes by ticks is very common in India (Pandit et al., 2011). About 41 species belonging to Ixodidae and Argasidae comprising 10 genera were collected from North-Western India. The genus Amblyomma (Koch, 1844) is one of the largest within Ixodida, and includes 130 species (Horak et al., 2002), of which twenty-four species have been recorded in Mexico parasitizing amphibians (2 species), reptiles (6), birds (2) and mammals (14), distributed mainly in the Neotropical region (18 tick species). Sanyal and De (1992) recorded Amblyomma helvolum parasitizing on a reptilian host. Ghosh and Misra (2012) described both male and female Amblyomma gervaisi by using scanning electron microscope (SEM). Piazak (2005) described the genus Amblyomma ticks which are large and beautifully ornamented with long mouth parts; possessing eyes and festoons. According to the traditional identification key to the genus Amblyomma, both sexes of the sole representatives of this genus have eyes and festoons (Bedford, 1932; Voltzit and Keirans, 2002). Several changes to the nomenclature of ticks were made. Klompen et al. (2002) considered that one subfamily; the Hyalomminae should be sunk, and Bothriocrotoninae have been created. Bothriocrotoninae and its sole genus Bothriocroton have been established to accommodate an early-diverging lineage of endemic Australian tick that used to be in the genus Aponomma. The remaining species of the genus Aponomma have been moved to the genus Amblyomma. Thus the name Aponomma is no longer a valid generic name. So far, the taxonomy of the ticks is based on the morphology and molecular studies (Dobson and Barker, 1999; Horak et al., 2002; Klompen et 
al., 2002; Barker and Murrell, 2004) where the genus Aponomma is considered as junior synonym of Amblyomma. Taxonomic and light microscopy studies on reptilian ticks are available (Barnard and Durden, 2000; Kenny et al., 2004; Durden and Knapp, 2005; Reeves et al., 2006). So far, limited studies on scanning electron microscopy observation of reptilian tick including Amblyomma have been reported (Durden et al., 2002; Barros-Battesti et al., 2005a, b; Beati et al., 2008; Onofrio et al., 2008; Ghosh and Misra, 2012).

The present study describes detailed surface ultrastructure of an ixodid tick, Amblyomma helvolum infesting on Bungarus fasciatus sand Naja kaouthia, which unravels the sexual dimorphism between male and female individuals. This study also tries to develop some taxonomically important specific characters, which may be useful in biosystematics of ixodid ticks.

\section{MATERIALS AND METHODS}

\section{Materials}

Both adult male and female ixodid tick, Amblyomma helvolum (Koch 1844) were collected from the snake host from six districts of West Bengal, India and were identified by the Zoological Survey of India, Calcutta, India.

\section{Taxonomic position}

Phylum Arthropoda
Class Arachnida
Order Acarina
Suborder Ixodida
Family Ixodidae
GenusAmblyomma
Species A. helvolum (Koch, 1844)

\section{Host}

Bungarus fasciatus and Naja kaouthia (family Elapidae) harbour Amblyomma helvolum. Three Bungarus fasciatus

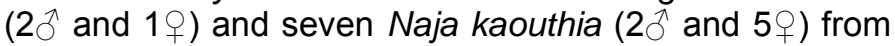
natural habitat and eleven Bungarus fasciatus ( 70 and 4 우)

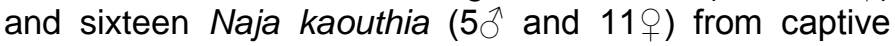
habitat were observed during specimen collection. Besides, 13 other snake species from both natural habitat and captive states were investigated for the ticks having such infection. However, only Amblyomma helvolum inhabiting on Bungarus fasciatus and Naja kaouthia were used for the present study.

\section{Area of collection}

The specimens (both adult male and female ticks) were collected from two host snake species (Bungarus fasciatus and Naja kaouthia) of both natural habitat and captive state in six districts (viz. Hooghly, Bankura, North 24 Parganas, Nadia, Bardhaman and Paschim Medinipur) of West Bengal, India.

\section{Site of infestation}

The site of infestation is the dorsal side of the snake.

\section{Procedure of collection}

The parasite ticks were gently pulled off, using two finger tips from its host body surface. During parasite collection the host snakes were caught by hand with the help of snake charmer. Seventeen adult individual ticks $\left(6{ }^{\hat{t}}\right.$ and 11 ) ) of both sexes were collected from two snake species Bungarus fasciatus and Naja kaouthia, of which 8 fresh individual ticks $(4 \hat{\circ}$ and 4 ㅇ) were isolated for SEM observation.

\section{Scanning electron microscopy preparation}

Snake's ticks were collected from different districts of West Bengal. After collection the specimens were kept in a container for few hours. The SEM studies were done on the adult stages of eight individual $A$. helvolum ( $4 \curvearrowright$ and 4 ).

During their free movement in the container several debris attached in their mouth parts like snake's scale falls off. Then, they were narcotized in benzene vapor and fixed in cold Karnovsky's Fixative (3\% glutaraldehyde and $2 \%$ paraformaldehyde) at $4^{\circ} \mathrm{C}$ temperature (Hoyer et al., 1982) in $0.1 \mathrm{M}$ cacodylate buffer ( $\mathrm{pH}$ 7.2). All chemicals were purchased from Sigma, USA. After overnight fixation (about 24 hours), the specimens were then rinsed thrice with phosphate buffer saline (PBS) and double distilled water at 15 minutes intervals. Any extracellular debris, such as the mucus, blood, other body fluids and tissue fragments that may obscure the surface to be examined were removed carefully. Fixed samples were further treated with $2 \%$ osmium tetroxide at room temperature for 4 hours for better conductivity. Samples were rinsed twice with PBS followed by double distilled water and gradually dehydrated in ascending grades of alcohol. The samples were finally dehydrated in a critical point dryer by using liquid $\mathrm{CO} 2$. Ticks were then attached with double-sided carbon tape to aluminum stubs and coated with gold in a sputter-coater (Polaron SC7620). The surface topography of specimens were examined under scanning electron microscope (FEl- Quanta200, operated at $20 \mathrm{kV}$ ), at Regional Sophisticated Instrumentation Center (RSIC), Bose Institute, Kolkata, India. Rest of the fixed samples was kept in laboratory in $80 \%$ alcohol. 


\section{Observation}

\section{Male tick (Figures 1a-f, 2a-f)}

The male $A$. helvolum is almost round in shape on its dorsal idiosomal portion (Figure 1a). A chitinous shield, known as scutum covers the entire dorsal idiosoma (Figure 1a). The scutum surface possesses several pores. Patterns of the distribution of these pores are remarkable(I) densely arranged pores are located on the lateral and posterior sides of the scutum, whereas (II) pores are few at the middle of two cervical grooves and also on the middle region of the dorsal scutum surface (Figures $1 \mathrm{a}$ and $1 \mathrm{e})$. Few pores have a tough bristle. Two comma shaped cervical grooves present on the anterior scutum, just below the emergination line (Figure 1a). Uneven ridges are found at the floor of each cervical groove (Figure 1d). No eyes are found on the antero-lateral sides of the dorsal scutum. Two continuous lateral margins of dorsal scutum are smooth whereas the posterior margin possesses eleven festoons (Figure 1a and 2b). Between two successive festoons an oval shaped deep groove is present. The inner surface of this groove exhibits uneven ridges. Both sides of antero-lateral edge of scutum are arched to form shoulder blades or scapula, which are inwardly curved towards both sides of the emergination line between the anterior gnathosoma or capitulum and posterior idiosoma Figures 1e and 1f). On ventral idiosoma pre-genital plate extends from the emergination line up to the genital orifice (Figure 1b). Male genital organ is situated on the middle region of convex half-moon-shaped genital plate. Median plate is situated between genital plate and anal plate. After the median plate, anus present on half circled anal plate (Figure 1b). Two adanal plates are present on the both sides of anal plate. Behind each spiracle, epimeral plate is extended up to adanal plate (Figure 1b). One pair of accessory adanal plates are extended from each side of third coxa up to the margin of epimeral plate (Figure 1b). The accessory adanal plate is maximum broad near the forth coxa and encircles it. Eleven festoons on ventral side are prominent and curved inwardly (Figure 1b).

Gnathosoma and Basis capituli: The gnathosoma is extended from the hypostomal tip to the emergination line (Figure 1e). The basis capituli is flask shaped and possesses the dorsal mandible, a ventral hypostome, and a pair of lateral sensory palp (Figures $1 \mathrm{e}$ and 1f). The dorsal surface of the basis capituli is smooth and has few pores (Figure 1c). A sharply pointed bristle present on the dorsal basis capituli (Figure 1c). Lateral margins of basis capituli are rounded; posterior margin is straight and cornua is absent in the male. Dorso-lateral sides are slightly convex. A short neck-like structure is present between the dorsal basis capituli and the emergination line (Figure 1e). The ventral side of the basis capituli is almost round in shape; smooth surfaced and has no such pores (Figure 1f). Few spines are present at the ventro- lateral side (Figure 1f).

Mandible: The anterior portion of the dorsal basis capituli is extended to form the mandible (Figure 1e). A central deep furrow is present at the mid line of the mandible, which extends up to the tip and divides the mandible in two symmetric parts. The tip of each symmetric half has cheliceral tooth (Figure 1e). A short licking organ present between two symmetric parts (Figure 1e). The surface of the anterior part of mandible possesses a remarkable arrangement of scales (Figure 1e).

Hypostome: The hypostome is originated from the middle part of ventral basis capituli (Figure 1f). It is a single elongate spatulate structure, lying ventral in close apposition to the mandibular sheath. A single toothless midline divides the hypostome in two symmetrical halves (Figure 2a). The inverted flower-vase like hypostome consists with definite arrangement of denticles (Figures $1 \mathrm{f}$ and 2a). Several short pointed denticles form two separate clusters at the tip of ventral hypostome, known as crown or corona. Comparatively large denticle on the middle length of hypostome is arranged in six rows. The dental formula is $3 / 3$. Each tooth terminates distantly in a pointed apex. Each row overlaps on the succeeding row. On the lower one-third portion of the hypostome, the denticles are reduced in size and looks like scales. The length of ventral hypostome and dorsal mandible are almost equal.

Palp: A pair of sensory palp is extended from the both ventro-lateral sides of the basis capituli (Figure 1f). The surface of the palp is wrinkled and consists of sensory hairs, arranged in rows. Each palp in its length consists of four segments, of which, middle two articles are fused together, hence only three segments are visible (Figures $1 \mathrm{e}$ and 2a). Suture between two successive palpal articles is prominent. The sensory bristles present on the palp have wonderful anatomical features. The tip of each bristle is bifurcated to form a brush like structure (Figure 2a). Bristles on dorsal portion is comparatively thick than ventral side of the palp. Bristles are present mainly on the lateral sides of the palp. Tip of the palp is well organized and a rounded head-like structure with densely packed pointed sensory bristles is projecting outward from a comma shaped depression (Figure 2a). The most contrasting anatomical features of the sensory bristles present on the palp is that, the bristles on the palpal head are pointed, thin and short, whereas the sensory bristles present on the lateral side of the palp are comparatively thick, long and bifurcated at the tip (Figure 2a). Palps are closely adhering to the hypostome. The base of the palp is firmly attached with the ventro-lateral side of the basis capituli. Each palpal base (the rudiment coxa) possesses a triangular spur (Figure 1f).

Appendages: Four pairs of appendages are attached on the ventro-lateral side of idiosoma (Figures $1 \mathrm{a}$ and $\mathrm{b}$ ). 

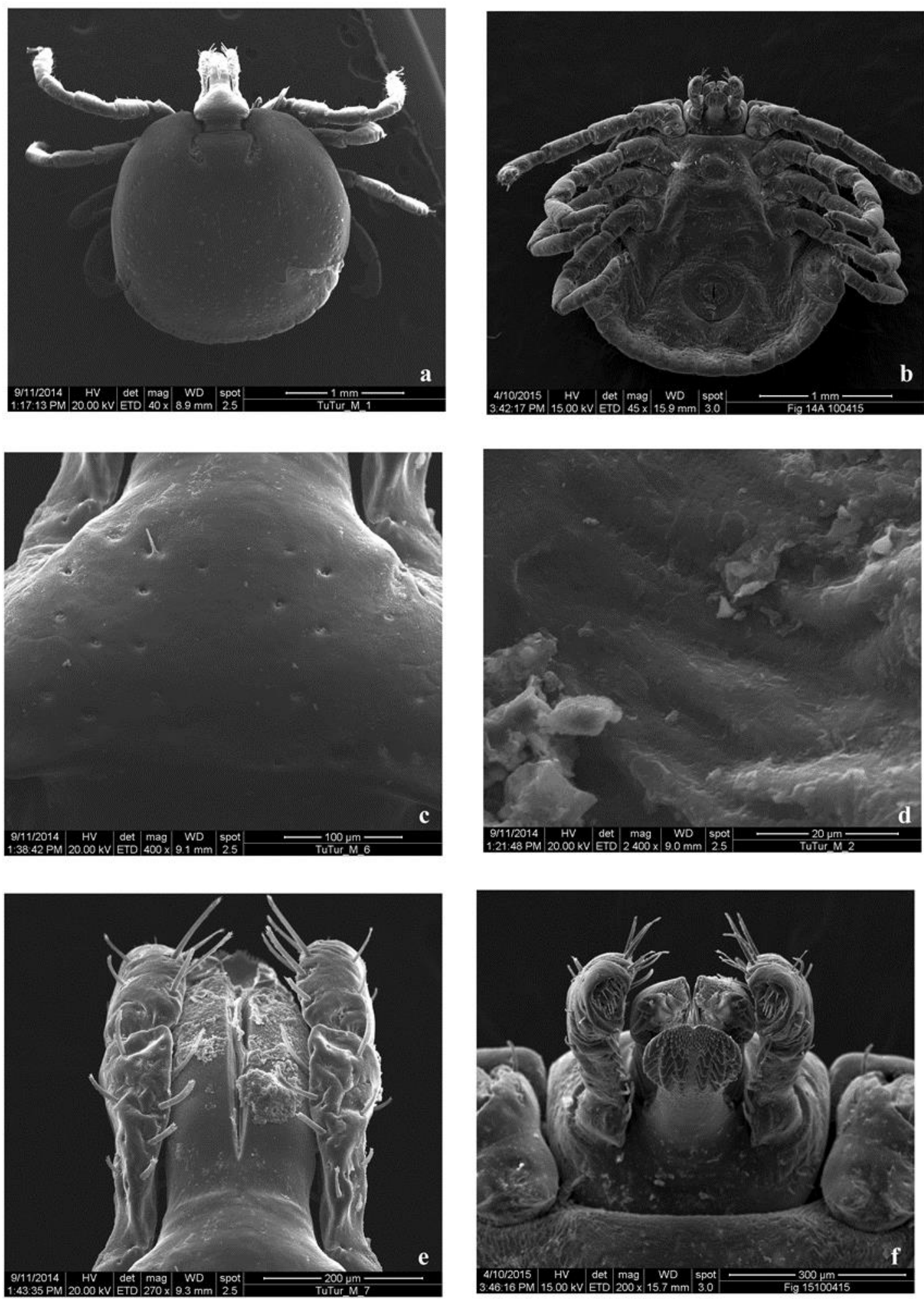

Figure 1. Scanning electron micrographs (SEM) of male Amblyomma helvolum. a. Dorsal view of the whole body of a male tick. Note the basis capituli, comma-shaped cervical grooves and two lateral palps. b. Ventral view of the whole body of the tick showing appendages, anus and genitalia. c. A close view of dorsal basis capituli showing few pores with a spine. d.A close view of cervical pits showing the distribution of uneven ridges within its floor. e. Enlarged view of the dorsal mandible, with central deep furrow and a pair of lateral palp. The serrated tip of the ventral hypostome is found.f. A close view of ventral gnathosoma shows the attachment of dorsal mandible with ventral hypostome. The palpal base and the coxa of first pair appendages bear spurs. 

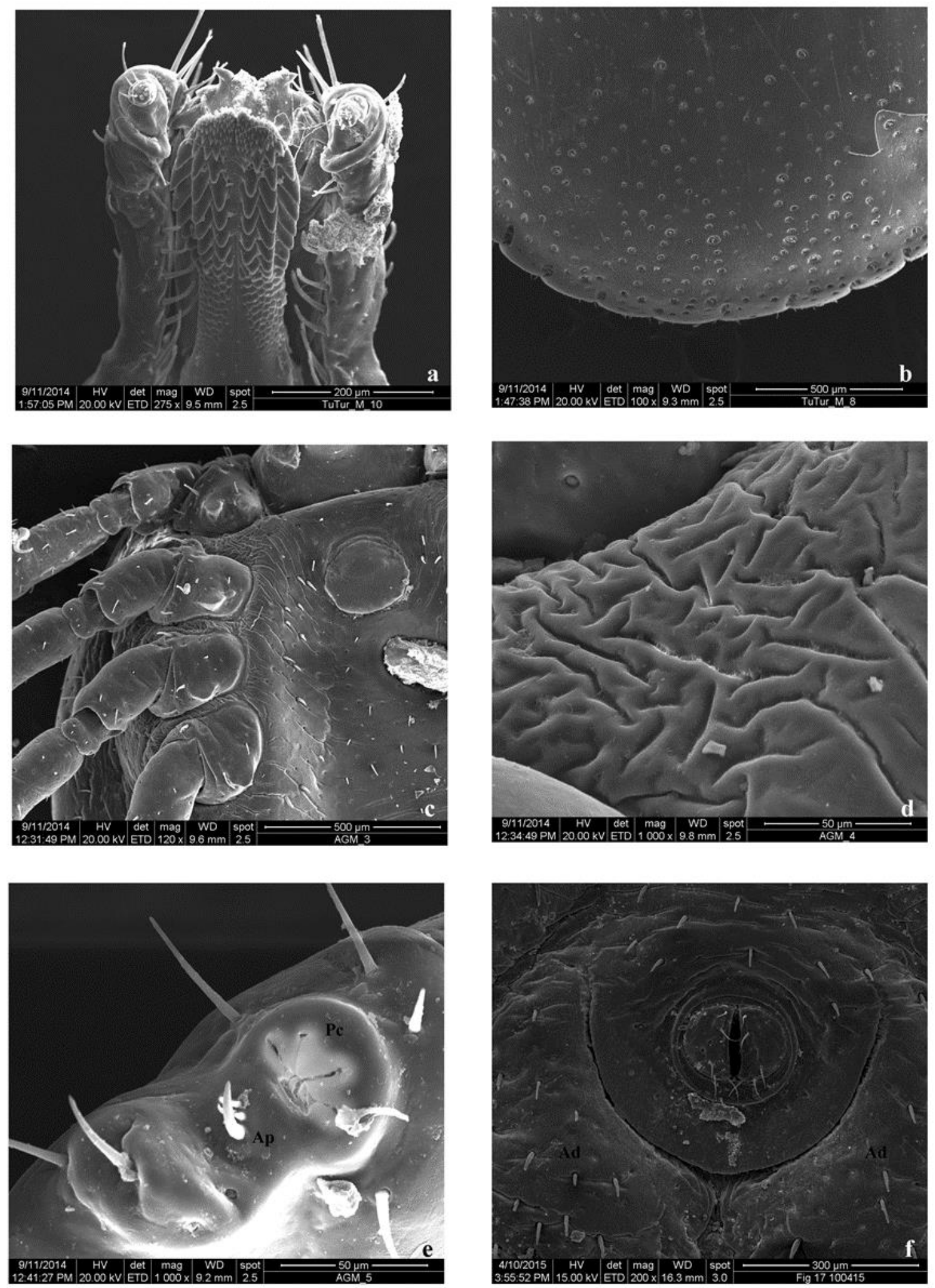

Figure 2. SEM photographs of male A. helvolum. a. The arrangement of denticle on hypostome and two lateral palps. b. The posterior margin of idiosoma shows the arrangements of festoons.c. Arrangement of spurs on the base of each appendicular coxa. d. Surface ultra-structure of the ventral idiosoma between two coxae showing shrinking surface texture with few very short setae. e. The horizontal '8' shaped Haller's organ on the first tarsus with anterior pit (Ap) and proximal capsule (Pc). f. Anus on half circle anal plate. Note two hairy anal valves and two adanal plates (Ad). 
Each appendage consists of seven segments; Coxa at the base, then trochanter, femur, patella, tibia, metatarsus and tarsus. Coxa of each appendage is loosely attached with the ventro-lateral side of the body; therefore, the appendages move freely (Figures $1 \mathrm{~b}$ and $2 \mathrm{c}$ ). Coxa I of first pair appendages bears two distantly placed cylindrical spurs (Figure 2c). These two internal and external spurs are almost equal in size. The external spur on the coxa I have a pointed bristle at its base. Coxa II of second pair appendages bears one broad and one very small spur. These two spurs are placed closely. Whereas the coxae III and IV of third and fourth pair appendages bears single broad spur. The short spur on coxa II and each spur on coxa III and IV have a tough pointed bristle. Several short stiff hairy bristles are scattered frequently on the appendicular segments (Figures $1 \mathrm{~b}$ and $2 \mathrm{c}$ ). Joints of the appendicular segments are attached by a soft articulating membrane (Figure 2c). Tarsus of each appendage bears an apotele or pre- tarsus with a pair of highly curved, sharply pointed claws (Figure 1b). The base of two claws of each pair is attached to a structure called pulvillus, which is attached with the apotele or pre- tarsus (Figure 1b). Comparatively large pointed bristles are present surrounding the base of pulvillus or at the distal end of the pre- tarsus (Figure 1b).

Haller's Organ: The surface ultrastructure of the Haller's organ of $A$. helvolum appears as the horizontal '8' (Figure $2 \mathrm{e})$. Proximal capsule and anterior pit is distantly situated with a distinct valley between them, thus appear as numerical ' 8 '. The anterior pit possesses four sensillum, of which one is thick and long than the others, two are medium size in length and equally thick and the remaining one is comparatively very short than other three sensilla. So, they can be grouped together in 1:2:1 ratio. The Hallaral capsule proximal to the anterior pit possesses four narrow and one comparatively thick slits, which forms four elevated pyramidal segments. A cuticular pore is located at a distance from the thick anterior pit sensillum. A specific hinge with a long pointed sensory bristle is present just opposite to the Hallaral capsule in respect to the anterior pit. Six to seven long sensory spines surround the Haller's organ.

Spiracle: Ventro-lateral to each fourth coxa, one pair of spiracle is present. Each spiracle is almost oval in shape of which the proximal one third portion is concave and the distal two third portion is convex (Figure 1b). A rounded bulging structure present on the concave surface. The distal end is comparatively tapering than the broader proximal end. The margin around the spiracle is prominent. The convex margin of the spiracle is projected out than the postero-lateral margin of the dorsal scutum. Several small nodule-like structures (goblets) scatter frequently around the bulging structure (macula) on the concave surface. The surface of convex region is smooth and without bristle.
Genital organ: The male genital organ is almost round to oval in shape. It is situated on convex genital plate below the emergination line, between the second pair coxa (Figures $1 \mathrm{~b}$ and 2c). Upper surface is smooth and hairless. The bulging genital aperture projects outwardly from a cavity. Stiff bristles with bifurcated tip are present surrounding the genital orifice (Figure 2c). Several striations are sparsely distributed on the lateral surface around the genital aperture (Figure 2c). Upper surface is comparatively lightly striated than the lateral surface around the genital orifice.

Anus: Anus is present on the half circled anal plate (Figure 2f). The bulging anus projects outward from the anal margin. Two convex anal valves guard the anal aperture. A prominent circular anal margin is present around the anal valves. Anal pore is present in between the anal valves. Long thin hairy projections are present on the surface of the anal valves. The upper surface of the anal plate is striated but the lateral and lower sides are not striated. Few small stiff bristles are scattered irregularly on the upper surface of anal plate. Bristles present on the anal valves are comparatively long than the bristles on the anal plate. "U" shaped anal groove is located at posterior to anal plate.

\section{Female tick (Figures 3a-f, 4a-f, 5a-f)}

Each female ixodid tick, $A$. helvolum, is oval in shape and the posterior margin is slightly wider than the anterior idiosoma (Figure 3a). The females are comparatively larger than the male tick. Body is dorso-ventrally flattened and divided into the anterior gnathosoma and posterior idiosoma. Gnathosoma extended from palpal apices to the posterior margin of the basis capituli and idiosoma extended immediate behind the basis capituli to posterior extremity of the body (Figures $3 a$ and $b$ ). The dorsal gnathosoma consists of one pair oval-shaped porose areas (Figures $3 c$ and $d$ ). Anteriorly a small portion of dorsal idiosoma is covered with a hard, smooth surface chitinous shield, which is known as scutum (Figure 3a). Numerous pores are randomly arranged throughout the scutal surface (Figures $3 a, 3 e$ and $4 d$ ). Few pores consist of single setae. One pair of elongated comma- shaped cervical groove is present on the scutum, just below the emergination line, where the basis capituli terminates (Figures $3 a$ and e). The floor of each cervical groove exhibits uneven ridges (Figure $3 e$ ). Eyes not present on the antero-lateral sides of the scutum. Both antero-lateral extremity of the dorsal shield is inwardly curved towards basis capituli to form angular shoulder blades or scapulae. After the scutum, the surface of the dorsal idiosoma, also known as alloscutum, is finely folded, appears as striations and extend continuously up to the end of body (Figures 3a and $4 d$ ). Several thick bristle-like projections are present on the alloscutal surface (Figure 4d). Some elongated long 

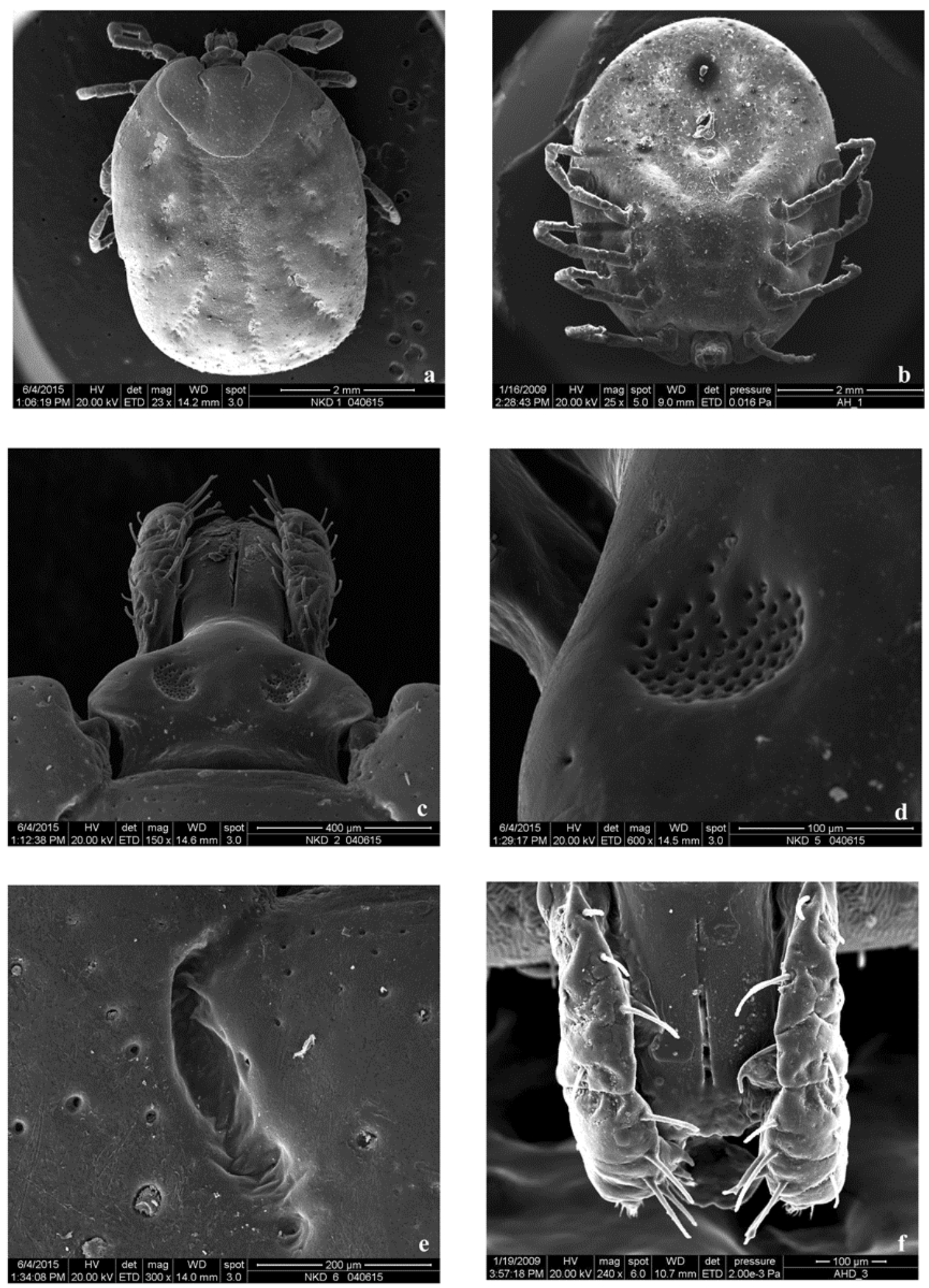

Figure 3. SEM photographs of female $A$. helvolum. a. Dorsal view of the whole body of a female tick. b. Ventral view of a female tick showing appendages, genitalia and anus. c. The dorsal view of gnathosoma showing triangular basis capituli, mandible and one pair of palp. Two porose regions present on the dorsal basis capituli. d. An enlarged view of a porose region on the dorsal surface of basis capituli. e. Cervical pit shows distribution of uneven ridges within its floor. f. A close view of the mandible and one pair of palp. The central furrow is fused at the tip of mandible. Lateral side of the palp bears some long spines, dorsal view. 

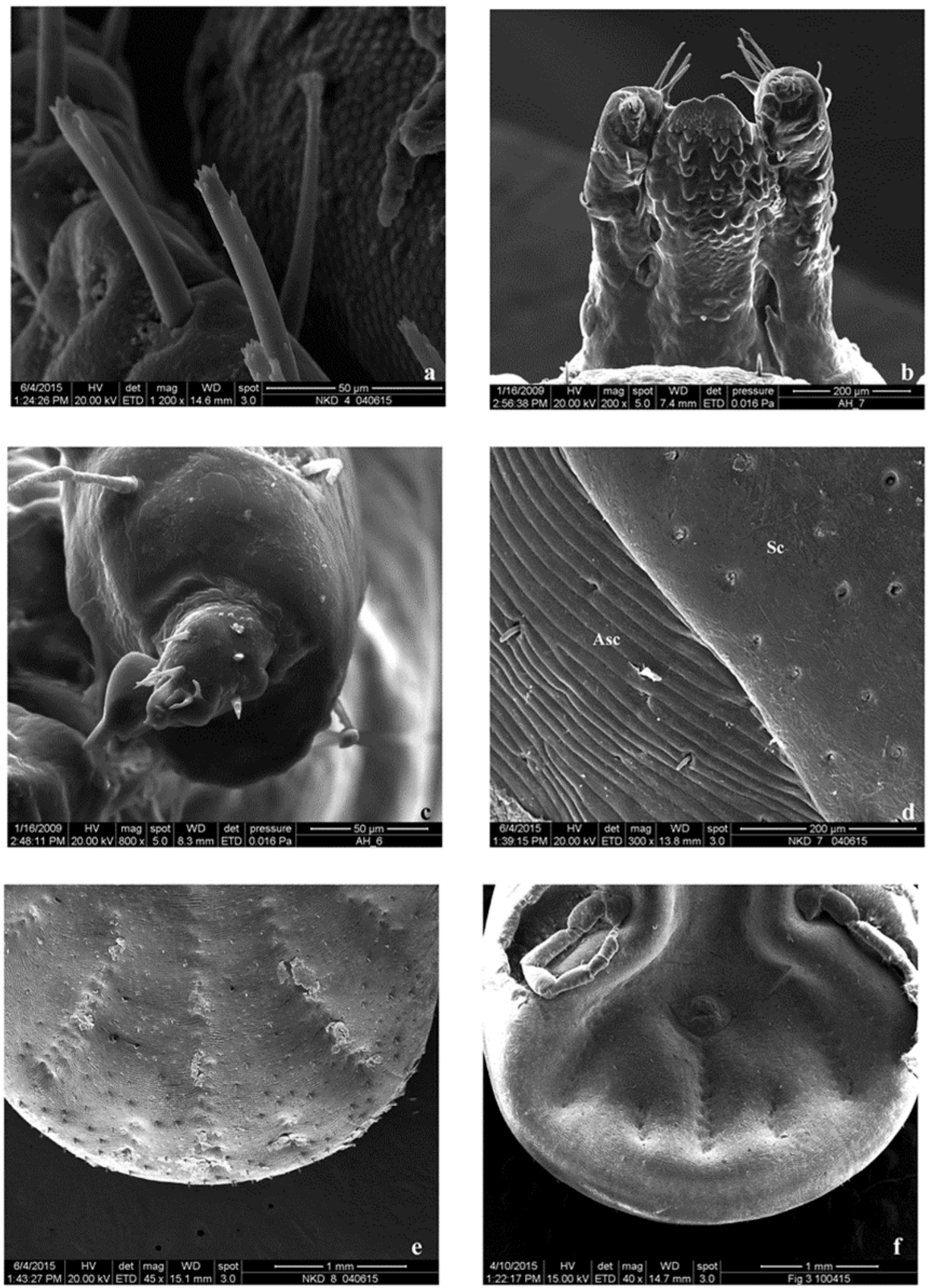

Figure 4. SEM photographs of female A. helvolum. a. Magnified view of palpal sensilla shows bifurcated tip. b. Ventral view of the hypostome shows rows of blunt denticle ( $3 / 3$ arrangements) and two lateral palps. c. A close view of the tip of palp shows the rounded head with few sensory bristles. d. Close view of idiosoma shows surface ultra-structural differences between scutum (Sc) and alloscutum (Asc). e. The posterior margin of idiosoma has no festoons, dorsal aspect. f. The ventral idiosomal extremity. 
and short depressions on the alloscutal surface are arranged in a specific architectural pattern (Figures $4 a$ and e). The posterior body margin does not possess festoons (Figure $s 4 e$ and f).

Ventral surface of idiosoma does not possess any plate except the anal plate (Figure $s 3 b$ and $5 f$ ). There is no pregenital, genital, median, adanal and accessory adanal plate on the ventral surface of idiosoma. The total ventral body surface is finely folded, appears as striations, which extends continuously up to the posterior extremity, except the half circled anal plate (Figures $3 b, 5 a, c$, e and f). Several bristle-like projections are scattered on the surface of the ventral idiosoma (Figures 5a, c, e and f).

Gnathosoma and Basis capituli: Female A. helvolum possesses broadly triangular basis capituli. Both dorsolateral sides are extended to form angular cornuae. Posterior margin is slightly concave. It bears the mouth parts that consist of a mandible, a hypostome and a pair of sensory palp (Figure 3c). It is connected with idiosoma by a soft articulating membrane, which allows the capitulum to be fixed (ventrally) or extended (returned to the horizontal axis), from the emergination (Figure $3 \mathrm{~b}$ and c). Two oval porose areas are situated on the smooth dorsal surface. A distinct smooth surface separates two porose areas. Little free pores are also seen on the surface beyond the porose area on dorsal basis capituli (Figures $3 c$ and d). The basis capituli is closely attached with the idiosoma at its ventral side (Figure 3b).

Mandible: The anterior part of dorsal basis capituli extends to form the mandible (Figure 3c). It is comparatively short in length than ventral hypostome and lateral palp (Figure 3f). A central deep groove (furrow) extends on the mid-line of dorsal mandible (Figure 3f). The furrow is fused at the tip. Posterior surface of the mandible shows numerous minute scales (Figure 4a).

Hypostome: It is the extending part of ventral basis capituli. Hypostome is elongated, spatulate, lying ventral in close apposition to the mandibular sheath. It is longer than the mandible. Dorsal surface at the tip of hypostome is smooth but wavy (Figure $3 \mathrm{f}$ ). The denticles on the distal portion of ventral hypostome are arranged in rows, each of which overlaps on the succeeding row (Figure 4b). Each tooth terminates distantly in a blunt apex. The denticle surface is smooth and dental arrangement is bilaterally symmetrical. The dental formula is $3 / 3$. Several minute teeth form two clumpy regions at the tip, known as crown or corona. On the lower half of the hypostome the denticle are successively reduced in size and form a wavy surface (Figure 4b).

Palp: Two extending sensory palps originate from each ventro-lateral side of the basis capituli and are closely associated with mandible and hypostome (Figures 3c, $f$ and $4 \mathrm{~b}$ ). Each palp consists of four articles and longer than the dorsal mandible and ventral hypostome (Figures $3 f$ and 4b). Two articles (II and III) are fused together; hence only three segments are visible (Figure 3f). Suture between two successive palpal articles is prominent. Surface is wrinkled but smooth and consists of several long needle-like sensilla, which are arranged in rows (Figures $3 c$, $f$ and $4 a$ ). Sensilla are mainly located on the dorso-lateral sides (Figure $3 c$ and f). Ventro-lateral side has very little sensilla (Figure 4b). Tip of the palp is elongate-oval structure with densely packed sensilla, which are comparatively shorter in length than the sensilla present on the dorso-lateral surface (Figures $3 f, 4 a$ and $c$ ). Palpal head is projecting out from a round base (Figure 4c). Sensilla on palpal body surface (dorso-lateral side) have a bifurcated tip, whereas the sensilla on palp head are pointed (Figures 3f, 4a and c).

Appendages: Four pairs of appendages are attached at the ventro-lateral side of the body (Figure $3 b$ ). Each appendage consists of seven segments; coxa at the base, then trochanter, femur, patella, tibia, metatarsus, and tarsus. Coxa of the appendages II- IV is rigidly attached with the body than the first pair of coxa, which is comparatively loosely attached (Figure 3b). Coxa I of the first pair appendages possesses two (external and internal) spurs and second, third and fourth pair appendages possesses single spur (Figure $3 b$ ). All the spurs on coxae I-IV are pointed. Spurs on coxa I are equal in length. Few short stumpy bristles are frequently distributed on the appendages. Joint of two succeeding segments of each appendage are attached by a soft articulating membrane that allows the appendicular segments to move freely (Figure 5a). Tarsus of each appendage bears an apotele or pre-tarsus with a pair of highly curved, sharply pointed claws. The bases of paired claws are attached with the pulvillus, which is the modification of the distal end of pre-tarsus. Haller's organ is located on the dorsal surface of the first pair tarsus.

Haller's Organ: The Haller's organ on first tarsus of female A. helvolum is looks like horizontal ' 8 ' (Figure $5 b$ ). The lateral side of the whole organ is irregular and wavy. The number, size and distribution of anterior pit sensilla and the slits on proximal capsule are almost similar to that of male. A specific hinge with two sensilla at the base is situated opposite to the Hallaral capsule in respect to the anterior pit. Few long sensory spines surround the Haller's organ. The organ is somehow angular in shape than the male $A$. helvolum.

Spiracle: One pair of respiratory organ, spiracle is present ventro- laterally, behind each of forth coxa (Figure 5c). Each spiracle is elongate-oval in shape, distal portion of which is slightly tapering, wide at middle region in female A. helvolum (Figure $5 \mathrm{c}$ ). The proximal part of the spiracle is concave and the distal region is slightly convex. Margin around the spiracle is prominent and there have no setae 

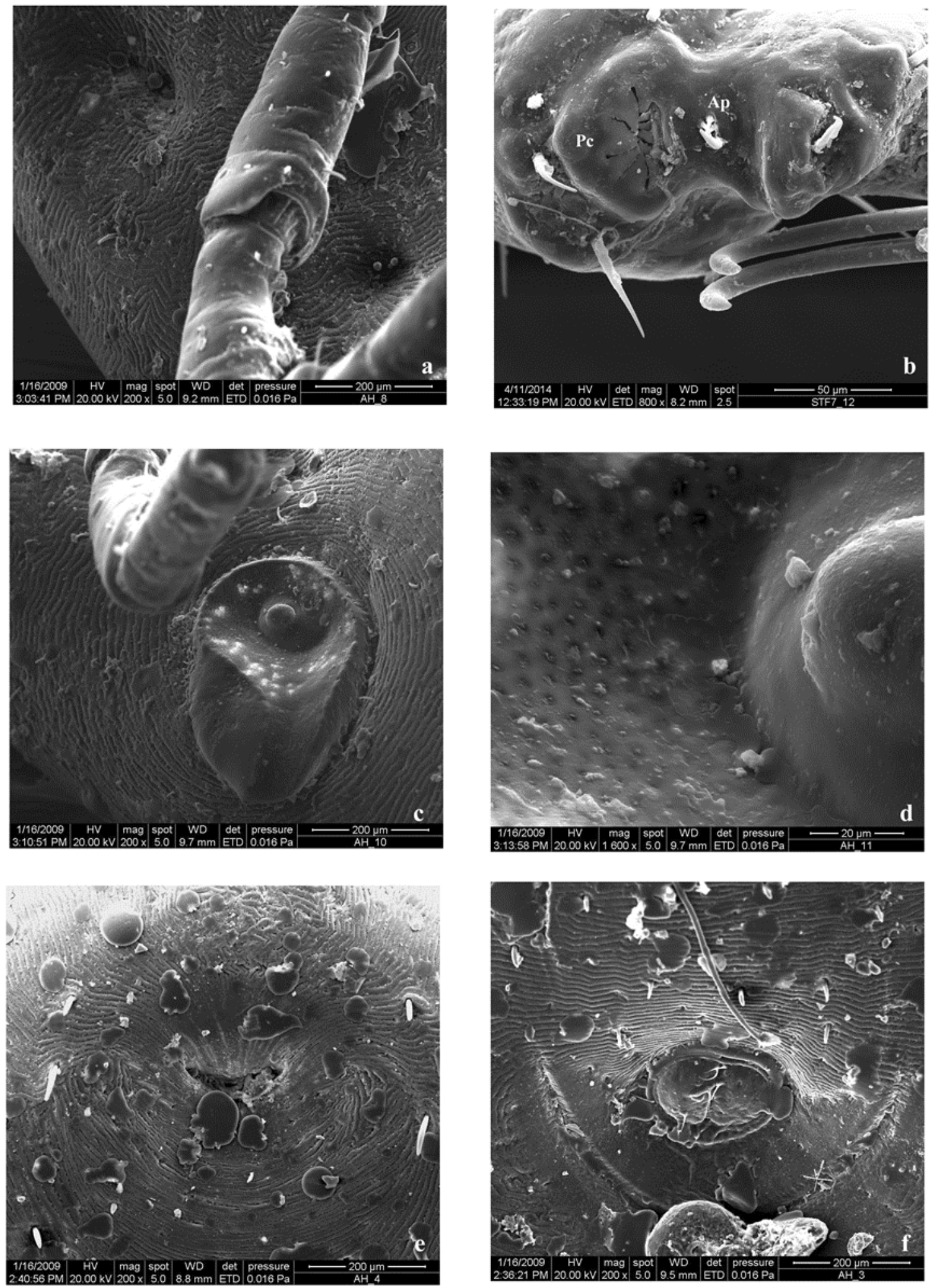

Figure 5. SEM photographs of female A. helvolum. a. A close view of the Joint of two appendicular segments. b. The horizontal ' 8 ' shaped Haller's organ on the first tarsus with anterior pit (Ap) and proximal capsule (Pc). c. A close view of the oval shaped spiracle. d. A magnified view of the surface ultra-structure of the spiracle shows porous surface texture and a round bulging aperture on the concave portion. e. The female genital organ shows eccentric slit. f. Bulging anus on the anal plate. Note spines present on the anal valves. 
on the surface. A round bulging structure (macula) is situated on the concave surface. Around the smoothly surfaced macula, the concave surface consists of several pores (Figure $5 \mathrm{~d}$ ).

Genital organ: An eccentric slit-like female genital organ is situated in the median line immediately below the basis capituli and between the second pair of coxa (Figure 3b). There is no genital plate around the genital orifice (Figure $5 e)$. Beyond the genital pore, several striations are densely arranged. Few short spines are sparsely distributed around the genital organ (Figure 5e).

Anus: Bulging anus is present on the half circled anal plate and possesses two anal valves, projecting outward from the anal margin (Figure 5f). Anal pore is present between two anal valves. Around the anal valves a prominent circular anal margin is present. Few needles like sensilla are projecting outward from the anal valve. Sensilla present on anal valve are comparatively longer than the spines present on the ventral surface of idiosoma. There are no striations on the surface of anal plate, whereas the striations are present on rest of the ventral idiosomal surface. "U" shaped anal groove is located at posterior to anal plate.

\section{DISCUSSION}

Disease contamination among snakes may be mediated by ticks which should be properly taken care of. Robinson (1926) recorded two ixodid tick species viz., A. helvolum and $A$. javanensa from Geomyda grandis and Manis pentadactyla respectively in Zoological garden, Kolkata, West Bengal. Later Sanyal et al. (1990) also recorded $A$. helvolum from Varanus $\mathrm{sp}$. and Naja naja from the same place. A detail monograph on the fauna of ixodid ticks in West Bengal was published (Sanyal and De 1992), which include five different hard tick species viz., Amblyomma helvolum, A. javanensa, A. supinoi, Aponomma gervaisi and Aponomma lucasi infecting on thirteen reptilian host species. Voltzit and Keirans (2002) published a review on Asian Amblyomma species. The article recorded the genus Amblyomma of Asia containing 14 species. SEM study of a snake associated tick, $A$. gervaisi from natural habitat was undertaken (Ghosh and Misra 2012), where sexual dimorphism of $A$. gervaisi was established. Later, Ghosh et al. (2017) provided a detail microscopic anatomy of the Haller's organ of $A$. gervaisi and $A$. helvolum by using SEM and TEM.

The SEM observation of both male and female $A$. helvolum in present work is discussed against the available SEM and light microscopical studies on other hard ticks species made by Kang and Jang (1985) in Ixodes persulcatus, Durden et al. (2002) in Amblyomma geochelone, Barros-Battesti et al. (2003) in Ixodes (Multidentatus) paranaensis, Barros-Battesti et al. (2005a) in Amblyomma fuscum, Piazak (2005) in Amblyomma lepidum, Barros- Battesti et al. (2007) in Amblyomma romitii, Onofrio et al. (2008) in Amblyomma varium, Beat et al. (2008) in Bothriocroton oudemansi, Labruna et al. (2009) in Amblyomma parkeri, Amblyomma longirostre and Amblyomma geayi, and Ghosh and Misra (2012) in Amblyomma gervaisi.

Structure of the basis capituli of ticks differs among the species. It is dorsally broad in male and female $I$. persulcatus, A. geochelone, I. paranaensis and male $B$. oudemansi. Basis capituli is rectangular in male $A$. fuscum, A. lepidum, A. romitii and $A$. varium. Male $A$. parkeri, $A$. longirostre, $A$. geayi and female $A$. fuscum, $A$. romitii, $A$. varium, B. oudemansi, A. parkeri, A. longirostre, and $A$. geayi have triangular or slightly trapezoidal basis capituli. Dorsal basis capituli of male A. parkeri, A. longirostre, and $A$. geayi possess numerous small punctuations (Labruna et al., 2009).

Basis capituli is flask-shaped in both sexes of $A$. gervaisi and male $A$. helvolum whereas female $A$. helvolum has broadly triangular basis capituli. Few pores are scattered on the dorsal basis capituli of these two species. Two spines in $A$. gervaisi and one spine in $A$. helvolum are observed on dorsal basis capituli, whereas such spines are not recorded from other species. Two light, straight diagonal striations present on dorsal basis capitulum of male $A$. gervaisi, whereas the structure is absent in both sexes of $A$. helvolum. Dorso-lateral sides are slightly concave and convex in $A$. gervaisi and $A$. helvolum respectively.

One pair of porose area present on the dorsal surface of basis capituli of female ticks. Porose area is moderate in size and deeply depressed in A. geochelone; ovoid, well delineated and slightly separate from each other in $I$. paranaensis; transversely elongated in $A$. fuscum and $A$. varium; large spherical in $A$. romitii; well delineated, depressed, pyriform and slightly divergent at anterior side in $B$. oudemansi; longitudinally elongated in A. gervaisi; and oval shaped and distinctly separated in $A$. helvolum.

Length of hypostome are of two types among the available hard ticks species revealed through SEM studies but the dental arrangement on the ventral hypostome shows several variations. Elongate and spatulate hypostome is found in male I. persulcatus, $A$. geochelone, A. fuscum, A. romitii, A. varium, B. oudemansi, A. gervaisi, and $A$. helvolum. Comparatively short, broad and bilobed hypostome is present in male I. Paranaensis, A. lepidum, $A$. parkeri, $A$. longirostre, and $A$. geayi. Length of hypostome in female ticks is elongated and spatulate of all the species so far described.

Dental formula differs among the tick species as seen through SEM. It is $3 / 3$ in male and female l. persulcatus, A. geochelone, A. parkeri, A. longirostre, A. geayi, A. gervaisi, $A$. helvolum and male $A$. varium, whereas $4 / 4$ in both sexes of $A$. fuscum, in male $A$. lepidum, $A$. romitii and female $A$. varium and $2.5 / 2.5$ in male and female $B$. oudemansi (Beati et al., 2008). 
Dental arrangement on hypostome in male I. paranaensis is somehow different from other ixodid tick species so far examined. Dental formula is $3 / 3$ on apical third, which is $5 / 5$ in median region and diminishing gradually towards the base. On the other hand, female $I$. paranaensis and $A$. romitii show some distinct hypostomal dental formula. The hypostome of female $I$. paranaensis has characteristics dental formula. It is essentially $3 / 3,2 / 2$ near base, $4 / 4$ on anterior third followed by a single $5 / 5$ row ending with $4 / 4$ at the corona (Barros-Battesti et al., 2003). Dental formula on ventral hypostome of female $A$. romitii is varying in different female types, such as $4.5 / 5,5 / 5,4.5 / 4.5$ and $6 / 6$ (Barros-Battesti et al., 2007).

Apical part of the ventral hypostome is rounded, with corona of fine denticle found in all the available hard tick species. Few specific characters of the hypostomal apex have been described in some tick species like as, a central notch present in male $A$. geochelone and $A$. romitii; two internally directed projections along the median line present in male $A$. varium and tip of the hypostome is slightly narrower in male $B$. oudemansi. Some species possess few specific characters like, apically pointed (lanceolate) corona of fine denticle in female $A$. longirostre; sub-acute corona in female $A$. geayi; corona is separated by a notch in female $A$. gervaisi and fused in female $A$. helvolum.

Hypostome is shorter than the palp in male $A$. parkeri, $A$. longirostre, A. geayi, A. gervaisi, and A. helvolum, whereas the hypostome is longer than the mandible in male $A$. gervaisibut equal to mandible in male $A$. helvolum.

Elongated slender palps are seen in male $A$. fuscum, $A$. lepidum, $A$. romitii, B. oudemansi, $A$. parkeri, $A$. longirostre, A. geayi, A. gervaisi, and A. helvolum, and are short and broad in male I. paranaensis (Barros-Battesti et al., 2003) and $A$. varium (Onofrio et al., 2008). Palp of the female individual of ixodid ticks are elongate in all the species studied so far. A rounded head like aperture with densely packed sensory bristles is projecting out from a comma shaped groove at the apex of each palp of male $A$. gervaisi and $A$. helvolum, whereas female $A$. gervaisi has few sensilla on the apex of palp but in female $A$. helvolum it is elongate-oval structure with few sensilla, projecting out from a rounded base. The structure of the head of the palp was not described earlier. Several sensory setae are distributed on the dorso-lateral sides of each palp of both $A$. gervaisi and $A$. helvolum.

The frontal part of dorsal basis capituli extends to form the mandible. Mandible is apically round in male $A$. gervaisi, whereas it divides into two symmetric parts in male $A$. helvolum. Apex of each part possesses cheliceral tooth in male $A$. helvolum, and absent in male A. gervaisi. Two triangular plates with numerous nodular structures and a pair of complicated dental structure present on the apical portion of mandible in female $A$. gervaisi, but are absent in female $A$. helvolum. A central deep furrow extends along the middle of mandible of both male $A$. gervaisi and $A$. helvolum. A short licking organ is found at the tip of mandible of these two male species. This furrow is continuous to the tip of mandible in female A. gervaisi, but fused at the tip of mandible in female $A$. helvolum. Such detail structure of mandible was not described in earlier SEM studies.

Dorsal surface of the male ixodid ticks is covered with a chitinous shield, known as scutum. Numerous punctuations are dispersed over this scutum. The distributions of these punctuations vary among different tick species. Punctuations are uniformly distributed in $I$. persulcatus, B. oudemansi, A. parkeri, A. longirostre, A. geayi and $A$. gervaisi. Such punctuations are irregularly distributed in $A$. geochelone, I. paranaensis, $A$. fuscum, $A$. lepidum, $A$. romitii, $A$. varium, and $A$. helvolum.

The female ixodid ticks possess a scutum covering the frontal part of dorsal idiosoma. Distribution of punctuations on dorsal scutum varies among the species. Punctuations on the scutum are numerous and deep in antero-lateral areas, otherwise are almost absent in female $A$. geochelone. Scutum is broad and elongate-oval, having very few punctuations in $I$. paranaensis. Triangularcordiform scutum of $A$. fuscum and $A$. varium possess near about large, deep and sparse punctuations close to eyes and cervical grooves and posterior and lateral margins have light punctuations, whereas $A$. gervaisi and $A$. helvolum both possess triangular scutum with broad anterior part and uniformly distributed punctuations. Large scutal punctuations are distributed uniformly all over the dorsal scutum surface of female $A$. goeldii and $A$. romitii (triangular scutum with moderately broad and rounded postero-lateral angles). Labruna et al. (2009) pointed out that $A$. parkeri, $A$. longirostre, and $A$. geayi have oval shaped scutum. Numerous large and deep punctuations are uniformly distributed over the scutal surface of $A$. parkeri and $A$. geayi, whereas these are concentrated on the antero-lateral fields of scutum of $A$. longirostre. Fine punctuations are uniformly scattered on the surface of the sub-triangular dorsal scutum of $B$. oudemansi (Beati et al., 2008).

Shape and size of cervical grooves differ among the tick species. It is comma shaped, moderate in length and deep in the anterior side in both sexes of $A$. geochelone, $A$. romitii, A. gervaisi, A. helvolum and in male I. paranaensis, and $A$. lepidum. Cervical grooves as short pits present in both sexes of $A$. varium, male $A$. fuscum, and female $I$. paranaensis. Male and female $A$. parkeri, $A$. longirostre, $A$. geayi and female $A$. fuscum possess very short, deep and comma shaped cervical grooves (Labruna et al., 2009). Cervical groove is very shallow in female $B$. oudemansi and is absent in male $B$. oudemansi. The floor of cervical grooves possesses uneven ridges in both sexes of $A$. gervaisi (Ghosh and Misra, 2012) and A. helvolum, which was not reported in earlier studies.

Well-developed lateral grooves are present on dorsal idiosoma of male $I$. persulcatus, $A$. geochelone, $A$. lepidum, B. oudemansi, A. parkeri, A. longirostre and $A$. geayi. Among these species lateral groove is incomplete 
in male $A$. longirostre (Labruna et al., 2009). On the other hand, lateral grooves are absent in male $A$. fuscum, $A$. romitii, $A$. varium, A. gervaisi, and $A$. helvolum.

Both antero-lateral extremity of the dorsal shield are inwardly curved to basis capituli to form scapulae. Prominent scapula is found in male and female $A$. geochelone, I. paranaensis, A. fuscum, A. romitii, $B$. oudemansi, A. gervaisi, and $A$. helvolum, whereas scapula is inconspicuous in both sexes of $A$. varium, A. parkeri, $A$. longirostre, and A. geayi.

Eye is an important organ of any species required for various purposes. Absence of eye may be a secondary adaptive character, the evolution of which is not yet explored. Presence of eye in the snake ticks is not a universal occurrence. Some species possess eye, whereas some exhibit eye spots and in some it is completely absent.

Eyes are present in A. geochelone; $A$. fuscum (large, flat and pale eyes); $A$. goeldii, $A$. lepidum (orbited eyes are small, dark-colored and hemispherical); $A$. romitii (large and pale eye); A. varium, A. parkeri, A. longirostre, and $A$. geayi (small, flat and pale), whereas absent in $I$. persulcatus, I. paranaensis, B. oudemansi, A. gervaisi, and $A$. helvolum. It is assumed that the function of eye must have been supplemented by other organ in eye less ticks. Thus, presence of eye in snake tick should not be considered as taxonomic character.

Paired and unpaired ventral shields are almost entirely covering the total ventral surface of maximum male ixodid tick species (Kang and Jang, 1985; Sanyal and De, 1992). The ventral idiosomal surface possesses single pregenital, genital, anal, and paired adanal and accessory adanal plates in $I$. persulcatus, $I$. paranaensis, $A$. geochelone, A. lepidum, B. oudemansi, A. parkeri, A. longirostre, A. geayi, A. gervaisi, and A. helvolum. Subrectangular jugular plates are extended internally to coxa I of first appendages in male I. paranaensis. Epimeral plates present behind each spiracle in $A$. paranaensis and $A$. helvolum. The jugular and epimeral plates were not reported in other available species including $A$. gervaisi.

Position of genital organ on ventral idiosomal surface varies among the species. Genital aperture presents in between of coxae II and III of second and third pair appendages in both sexes of $B$. oudemansi, in male $I$. paranaensis and female $A$. parkeri, $A$. longirostre, and $A$. gervaisi. It is located at the level of coxa II of second pair appendages in both sexes of $A$. fuscum, A. geayi, $A$. helvolum, in male $A$. lepidum, $A$. parkeri, $A$. longirostre, $A$. gervaisi and in female $A$. varium. On the other hand, genital aperture is located at the level of coxae I-II of first and second pair appendages in both sexes of $A$. romitii (Barros-Battesti et al., 2007) and female A. geochelone. Genital aperture of female I. paranaensis is present at the level of coxa III.

Shape and size of the spiracular plate differs among the species. Ovoid spiracular plate with centrally placed macula is found in male $I$. paranaensis, both sexes of $A$. gervaisi, A. helvolum and female I. persulcatus, whereas semi-oval and in dorso-ventral plane in female $I$. paranaensis. Spiracular plates are elongated and comma shaped in male $A$. fuscum and sub-triangular in female. It is large and triangular with rounded angles in male $A$. lepidum and female $A$. geochelone, whereas subtriangular and comma-shaped in female $A$. varium. It is large and elongated towards dorsal surface with festooned margins in both sexes of $A$. romitii, whereas large, broad and extruding from the external body margin in male and female $B$. oudemansi. Though the respiratory organ in both $A$. gervaisi and $A$. helvolum is oval in shape but structurally it is totally concave in male $A$. gervaisi, in male A. helvolum it is concave and convex at proximal and distal portion respectively, tapering at distal part in female $A$. gervaisi, and maximum width at middle region in female $A$. helvolum.

The posterior idiosomal extremity possesses distinct festoons in male and female $A$. geochelone, A. romitii, $A$. varium, B. oudemansi, A. parkeri, A. longirostre, A. geayi, A. gervaisi, and in male $A$. fuscum and $A$. helvolum. On the other hand, festoons are absent in female I. persulcatus and $A$. helvolum.

Anal groove is ' $U$ '- shaped and thick, located at posterior to anus in $A$. geochelone, $A$. fuscum, $A$. romitii, $A$. varium, $B$. oudemansi, A. parkeri, A. longirostre, A. geayi, A. gervaisi, and $A$. helvolum, whereas it is located at anterior to anus in $I$. persulcatus and $I$. paranaensis.

Distribution, shape, size and number of spurs (absent in few species) on all appendicular coxa of male ixodid ticks vary among the species. Each coxa I of first pair appendages bears two unequal spurs in male and female I. persulcatus (short external and long internal spur); $A$. geochelone (internal spur is slightly longer than external spur); $A$. fuscum (internal spur is slightly shorter than external spur); $A$. varium (internal spur is shorter than external spur), A. parkeri, A. longirostre, and $A$. geayi (external spur is two to three times longer than the internal spur), male $A$. lepidum (external spur is longer and more pointed than internal one) and female I. paranaensis (short internal spur with two setae and large external spur); $A$. goeldii (longer spurs and internal spur is slightly reduced in size than external spur); $A$. romitii (short, rounded spurs and internal spur is broader and slightly shorter than external spur) and A. gervaisi (two long pointed spurs, external spur is slightly short than internal one). Two equal spurs present on coxa $I$ in both sexes of $B$. oudemansi (rounded, short spurs), A. helvolum (long, pointed spurs), male $A$. romitii, and $A$. gervaisi. However, male $I$. paranaensis has one spur (small internal spur) on coxa I (Barros-Battesti et al., 2003).

Coxae II-IV each has one external spur in both male and female $A$. geochelone (spur on coxae II and III are broadly rounded and spur on coxa IV is longer and narrower); $I$. paranaensis (large equal sized spur on coxae II-IV); $A$. fuscum (short and flat spur on coxae II-III and triangular flat spur as broad as long on coxa IV); $A$. varium (rounded 
short spur on coxae II-III and large spur on coxa IV); $A$. parkeri, $A$. longirostre and $A$. geayi (small triangular spur); A. gervaisi (short flat spur on coxae II-III and triangular pointed spur on coxa IV in male and broad spur on coxa II, long and oval edged spur on coxae III and IV, each appendicular coxa bears two bristles like projections in female), male $B$. oudemansi (stout and rounded spur on coxae II-IV) and female A. helvolum (pointed spur on each of coxae II-IV). On the other hand, coxae II-IV have no spurs as such in female $B$. oudemansi. All these coxae have single external round protuberance.

Piazak (2005) described a broad, curved and salient ridge on each of coxae II-III of male A. lepidum. Coxae II and III have no spur as such. A single stout spur, twice as long as broad is present on coxa IV in male A. lepidum. Each of coxae II and III bears two short, rounded spurs in both sexes of $A$. romitii. Coxa IV possesses two short spurs, with external stout and three times longer than internal one (Barros-Battesti et al., 2007). Each coxa of second pair appendages of male $A$. helvolum bears closely placed two spurs (internal broad and external very small). Coxae III and IV have single broad spur. The external small spur on coxa II and spur on coxae III and IV have a tough pointed bristle on its base in $A$. helvolum.

According to the traditional identification key to the genus Amblyomma, the sole representatives of this genus have eyes (Bedford, 1932; Sanyal and De, 1992; Voltzit and Keirans, 2002). But in the present study the A. helvolum has no eye on the antero-lateral sides of the scutum. The presence of festoons at the posterior idiosomal extremity is common in both sexes of all representative species of the genus Amblyomma (Bedford, 1932; Voltzit and Keirans, 2002). Whereas the present study shows that female $A$. helvolum possesses no festoons at their posterior body extremity. So the identification key regarding the eye and festoons for the genus Amblyomma in the former studies should be reformed.

\section{Conclusion}

The important features of the present study include absence of festoons in the female tick, absence of eyes on the antero-lateral sides of the scutum, as well as the number of sensilla, slits and pyramidal regions on the Haller's organ of both sexes of this species. The outcome of the work has some contribution towards the biosystematics of snake ticks. Though there are many views regarding the origin and evolution of hard ticks (Dobson and Barker, 1999; Murrell et al., 2001a, b; Barker and Murrell, 2004) which consider mostly molecular information, it is time to include electron microscopic observations of the ticks to understand the adaptive convergence/divergence of the ticks in relation to the habitat of the snakes. Further works in this line would certainly strengthen biosystematics of snake ticks.

\section{ACKNOWLEDGEMENT}

The authors are thankful to RSIC, Bose Institute, Kolkata, India, for SEM observation. Specimens were identified by Zoological Survey of India, Kolkata, India. The authors (HSG, AKS and KKM) acknowledge the laboratory facilities from the Head of the Department of Zoology, Asutosh College, Kolkata.

\section{ORCID}

Himadri Sikhar Ghosh http://orcid.org/0000-0001-77462017

A. K. Sanyal http://orcid.org/0000-0002-9804-2801

K. K. Misra http://orcid.org/0000-0003-4909-3319

\section{REFERENCES}

Barker, S. C., \& Murrell, A. (2004). Systematic and evolution of ticks with a list of valid genus and species names. Parasitology, 129, S15-S36.

Barnard, S. M., \& Durden, L. A. (2000). A Veterinary Guide to the Parasites of Reptiles, Volume 2, Arthropods (Excluding Mites). Krieger Publishing Company, Malabar.

Barros-Battesti, D. M., Arzua, M., Pichorim, M., \& Keirans, J. E. (2003). Ixodes (Multidentatus) paranaensis n. sp. (Acari: Ixodidae) a parasite of Streptoprocne biscutata (Sclater 1865) (Apodiformes: Apodidae) Birds in Brazil. Memorias do Instituto Oswaldo Cruz (Rio de Janeiro), 98, 1-10.

Barros-Battesti, D. M., Arzua, M., Onofrio, V. C., \& Labruna, M. B. (2007). Validation and redescription of Amblyomma romitii Tonelli-Rondelli, 1939 (Acari: Ixodidae). Systematic Parasitology, 68, 79-86.

Barros-Battesti, D. M., Onofrio, V. C., Labruna, M.B., Martins, R., \& Guglielmone, A. A. (2005a). Redescription of Amblyomma fuscum Neumann, 1907 (Acari: Ixodidae), a rare South America tick confirmed in Brazil. Systematic Parasitology, 61, 85-92.

Barros-Battesti, D. M., Arzua, M., Rebello, V.M., Barbieri, F., \& Famadas, K. M.(2005b). Description of the larva of Amblyomma longirostre Koch, 1844 (Acari: Ixodidae) by light and scanning electron microscopy. Brazilian Journal of Veterinary Parasitology, 14, 51-57.

Beati, L., Keirans, J.E., Durden, L.A., \& Opiang, M.D. (2008). Bothriocroton oudemansi (Neumann, 1910) n. comb. (Acari: Ixodida: Ixodidae), an ectoparasite of the western long-beaked echidna in Papua New Guinea: redescription of the male and first description of the female and nymph. Systematic Parasitology, 69, 185-200.

Bedford, G.A. H. (1932). A synoptic check- list and host- list of the ectoparasites found on South African Mammalia, Aves and Reptilia. $18^{\text {th }}$ Report of the Director of Veterinary Series on Animal of Inland, S. Africa, 223- 523.

Dobson, S. J., \& Barker, S. C. (1999). Phylogeny of the hard ticks (Ixodidae) inferred from 18S rRNA indicates that the genus Aponomma is paraphyletic. Molecular Phylogenetics and Evolution, 11, 288-295.

Durden, L.A., \& Knapp, C. R. (2005). Ticks parasitizing reptiles in the Bahamas. Medical and Veterinary Entomology, 19, 326328.

Durden, L. A., Keirans, J. E., \& Smith, L. L. (2002). Amblyomma 
geochelone, a New Species of Tick (Acari: Ixodidae) from the Madagascan Ploughshare Tortoise. Journal of Medical Entomology, 39(2), 398-403.

Ghosh, H.S., \& Misra, K.K. (2012). Scanning electron microscope study of a snake tick, Amblyomma gervaisi (Acari: Ixodidae). Journal of Parasitic Diseases, 36, 239-250.

Ghosh, H. S., Roy, S., Sanyal, A. K., \& Misra, K. K. (2017). Microscopic anatomy of the Haller's organ of snake ticks. International Journal of Acarology, 43, 1-9.

Horak, I. G., Camicas, J. L., \& Keirans, J. E. (2002). The Argasidae, Ixododae and Nuttalliellidae (Acari: Ixodida): a world list of valid tick names. Experimental and Applied Acarology, 28, 27-54.

Hoyer, L. C., Bucana, C., Marchalorees, J. J., Warr, G. W., \& Wiley, J. (1982). In: Principles of Immunoelectron Microscopy. London.

Kang, Y. B., \& Jang, D. H. (1985). A description with scanning electron microscopy on the tick Ixodes persulcatus (Schulze 1930) male and female specimens. Korean Journal of Parasitology, 23(2), 305-312.

Kenny, M. J., Shaw, S. E., Hillyard, P. D., \& Forbes, A. B. (2004). Ectoparasites and haemoparasites risks associated with imported exotic reptiles. Veterinary Record, 154, 435-436.

Klompen, J. S. H., Dobson, S. J., \& Barker, S. C. (2002). A new subfamily, Bothriocrotoninae n. subfam., for the genus Bothriocroton (Keirans, Kang and Sharrad 1994) status amend. (Ixodida: Ixodidae) and the synonymy of Aponomma (Neumann 1899) with Amblyomma (Koch 1844). Systematic Parasitology, 53, 101-107.

Koch, C. L. (1844). Systematische übersicht über die Ordnung der Zecken. Archiv für Naturgeschichte, 10, 217-239.

Labruna, M.B., Onofrio, V. C., Beati, L., Arzua, M., Bertola, P.B., Ribeiro, A.F., \&Barros-Battesti, D. M. (2009). Redescription of the female, description of the male, and several new records of Amblyomma parkeri (Acari: Ixodidae), a South American tick species. Experimental and Applied Acarology, 49, 243-260.

Murrell, A., Campbell, N. J.H., \& Barker, S.C. (2001a). Recurrent gains and losses of large (84-109 bp) repeats in the rDNA internal transcribed spacer 2 (ITS2) of rhipicephaline ticks. Insect Molecular Biology, 10, 587-596.
Murrell, A., Campbell, N.J.H., \& Barker, S. C.(2001b). A totalevidence phylogeny of ticks provides insights into the evolution of life cycles and biogeography. Molecular Phylogenetics and Evolution, 21, 244-258.

Onofrio, V. C., Barros-Battesti, D. M., Marques, S., Faccini, J. L. H., Labruna, M. B., Beati, L., \& Guglielmone, A.A. (2008). Redescription of Amblyomma varium (Koch 1844) (Acari: Ixodidae) based on light and scanning electron microscopy. Systematic Parasitology, 69, 137-144.

Pandit, P., Bandivdekar, R., Geevarghese, G., Pande, S., \& Mandke, O. (2011). Tick infestation on wild snakes in northern part of Western Ghats of India. Journal of Medical Entomology, 48, 504-507.

Piazak, N. (2005). The first report of Amblyomma lepidum (Donitz, 1909) in Iran. Iranian Journal of Public Health, 34(2), 70-73.

Reeves, W. K., Durden, L. A., \& Dasch, G. A. (2006). A spotted fever group Rickettsia from an exotic tick species, Amblyomma exornatum (Acari: Ixodidae), in a reptile breeding facility in the United States. Journal of Medical Entomology, 43, 1099-1101.

Robinson, L.E. (1926). The genus Amblyomma, in: Ticks: a monograph of the Ixodoidea, Part IV. Cambridge University Press, Cambridge.

Sanyal, A.K., \& De, S.K. (1992). Ixodid Ticks (Acari: Ixodidae) State Fauna Series 3: Fauna of West Bengal, Part 3. 17-60.

Sanyal, A. K., De, S. K., \& Banerjee, S. (1990). Records of ticks (Acarina: Metastigmata) associated with reptiles in Zoological Garden, Calcutta. Records of the Zoological Survey of India, 87(4), 335-336.

Voltzit, O. V., \& Keirans, J. E. (2002). A review of Asian Amblyomma species (Acari, Ixodida, Ixodidae). Acarina, 10, 95-136. 